\begin{tabular}{ccc}
\hline International Journal of Engineering \& Technology, $7(3.4)(2018) 181-187$ \\
SPC & Website: www.sciencepubco.com/index.php/IJET \\
Research paper & Technology \\
\hline
\end{tabular}

\title{
Work-in-Progress Inventory Control Case Study in Lean Management
}

\author{
Hong Wai Tan ${ }^{1}$, Khairur Rijal Jamaludin², H S Hamzah ${ }^{3}$ \\ ${ }^{1}$ Razak Faculty of Technology and Informatics, Universiti Teknologi Malaysia Kuala Lumpur \\ Jalan Sultan Yahya Petra, 54100 Kuala Lumpur \\ ${ }^{2}$ Razak Faculty of Technology and Informatics, Universiti Teknologi Malaysia Kuala Lumpur \\ Jalan Sultan Yahya Petra, 54100 Kuala Lumpur \\ ${ }^{3}$ Razak Faculty of Technology and Informatics, Universiti Teknologi Malaysia Kuala Lumpur \\ Jalan Yahya Petra, 54100 Kuala Lumpur \\ *Corresponding author E-mail : thw4026@gmail.com:
}

\begin{abstract}
Increasing the rate of converting raw material into finished product and delivering it on time is a main driver for each manufacturing industry to achieve continuous improvement in its business operation. This case study demonstrates the improvement of the work-inprogress inventory in a non-lean company seeking to adopt lean management. Introducing the value stream mapping (VSM) lean technique to identify the waste in the current production operation. A selection of lean tools such as Kanban card, supermarket racking and one-piece flow are applied to control and monitor the WIP inventory after justification of the factors (process cycle time, production facilities layout and facilities capacity allocation) that influence the change from the current production operation situation.

The construction of the current VSM had identified the major waste in WIP inventory handling in the final fabrication process. The fluctuation of WIP inventory has been resolved by the implementation of supermarket racking; therefore, an improvement base for WIP inventory control has been established. Throughout this study, the lean management concept had been fostered into the production floor team and will continue developing to the organization.
\end{abstract}

Keywords: Continuous improvement, production system, work-in-progress, value stream mapping, lean management

\section{Introduction}

\subsection{Background to the Problem}

A company's performance can be classified into 3 dimensions: operational performance, financial performance and product quality. The inventory level performance is a common measure of a firm's operational efficiency in evaluating the management's ability to use resources effectively and efficiently [ 4 ]. Indeed, in a manufacturing firm, inventory turnover has a cause-and-effect relation with the manufacturing system [11]. A case study was established in company VP with a workforce of 85 in metal stamping to supply the local electronic and automotive industries. The management is facing three major shop-floor issues for the selected control board (part 219) assembly from its 4 sub-parts, 219A, 219B, 219C and 219D. The final fabrication of 219 involves spot welding;

Problem No.1. Lack of a holistic view of the overall waste in the product flow for the entire operation.

Problem No.2. Waste in material handling in the flow for the WIP inventory at the final fabrication process.

Problem No.3. Inconsistency of the production WIP inventory level for the sub-parts in each shop floor production plan resulting from large variance in the production process.

The above problems have driven the establishment of the case objectives. The first problem is the lack of a holistic overview of the waste in the entire operation. This can be overcome through the deployment of lean techniques for which constructing the value stream mapping to identify the waste is the first objective. In resolving problem No.2 relating to WIP inventory consistency, the second objective is to integrate a lean tool for managing the line WIP inventory and developing a new value stream mapping. The third objective is to integrate this tool to stabilize the WIP inventory level and ascertain the WIP inventory level base for continuous improvement.

\subsection{Work-in-Progress (WIP) in Manufacturing}

For decades, the speed of converting a raw material into finished product and delivering to the end user in an entire supply chain using optimum resources (less waste) has been the main challenge for all manufacturers. In actual floor operation, the purchased raw material or component has gone through various processes classified as work-in-progress (WIP) or semi-finished product. CuatrecasasArbós [5] mentioned that WIP is present in every manufacturing process that produces a finished product. Indeed, an unambiguous WIP condition on the shop floor is vitally important in demonstrating the inventory level and sequence of the processing. Hence, as claimed by Fang [7], the queueing timing determines the flexibility of the process response to the changing market demand. In day-today shop floor operation, a production leader has a significant function in tracking the WIP level and movement. As mentioned by Papadopoulos [12], the WIP level will determine the process effi- 
ciency and directly decide the production lead time. In manufacturing, the WIP level plays a vital role as an indication of the rate of conversion into the finished product.

\section{Literature Review}

\subsection{Work-in-Progress Issues}

Frequently, the shop floor team is unable to determine an exact completion time for a particular product or semi-product to meet the requirements of a downstream process in a continuous production flow. This results from the failure to identify the WIP status, especially in multiple production lines for various products. Industrial practitioners and researchers are continuously developing an optimum and robust methodology for monitoring WIP levels and servicing relevant processes. A case study from Oladipapo [3] of production control strategy selection of the WIP controlling policy, such as Kanban (general and extended), constant WIP and base stock control, in meeting the required servicing level with a minimised WIP level in a mixed-product production context with system instabilities. The author had found it hard to depend on a single optimal and highly robust control policy under varying levels of instability that resulted from various demands, set up times, breakdown times and processing times. Thus, under different circumstances, the application of Kanban extended, base stock or constant WIP would be introduced to obtain a minimum WIP level. In a traditional production strategy, Cuatrecasas-Arbós [5] had stated that a high level of WIP was intended to encounter the uncertainty and variability in the process whilst keeping the manufacturing process running.

On the contrary, in a Lean Manufacturing Environment, WIP is a form of waste in terms of handling costs and holding costs, however, WIP is unavoidable due to uncertainty on the production floor but it had to be minimised and visible. Another WIP part concern, mentioned by Savino [14], in many industries was the lack of knowledge about where and when the line supply strategy should be introduced to achieve best practice in their environment. As far as the final fabrication line with various sub-parts (WIP) was concerned, Savino [14] claimed that for part feeding in this type of line, it was, most of the time, workable to implement a mixed part feeding policy such as line storage and just-in-time delivery rather than implementing a single policy. Nonetheless, despite the production control strategy in managing line WIP, subsequently, nontrivial conditions such as ad-hoc planning are happening on the shop floor for notification of WIP movement in relation to a particular production batch. Encompassing this issue, several research studies have been carried out on tracking the WIP movement, for instance, by enhancing information technology, Zhang [18] had developed a framework for applying radio frequency identification (RFID) in identifying the real-time WIP movement. As mentioned above by researchers, their ultimate aim in their case study is keeping a lower WIP level, indeed the higher WIP level had resulted from ambiguous conditions in tracing WIP movement on the shop floor. In the study from Cuatrecasas-Arbós [5] in determining the production lead time, it is preferable to correlate a production lead time with the WIP level rather than the process cycle time. Another study from Ziengs [19] examined limiting the WIP level by creating a unit-base pull system to ease the determination of throughput time on the production line.

\subsection{Work-in-Progress Control in Lean Management}

The term "lean" means creating more value for interested parties with fewer resources. A lean organization understands interested parties' needs and focuses its key processes to continuously increase its value. In a lean manufacturing context, the WIP inventory has been classified as a form of waste, nonetheless, it is unavoidable on the production floor. From Ohno [17], the initial development of the Toyota Production System (TPS) from the lean concept was established based on just-in-time (JIT) materials provision thereby eliminating WIP in the production line. Several production strategies were implemented as the TPS evolved. As illustrated in Fig.1, the idea of a withdrawal by sequence process had introduced thinking about what is needed, when it is needed and how many are needed in between upstream and downstream processes. The establishment of the supermarket concept was developed to meet the various process requirements and simultaneously, the development of card ordering of supplies from outside the production line allowed them to be integrated into the process flow. As a means of continuously reducing line WIP in accordance with the JIT philosophy, the Kanban card call-in system was eventually implemented.

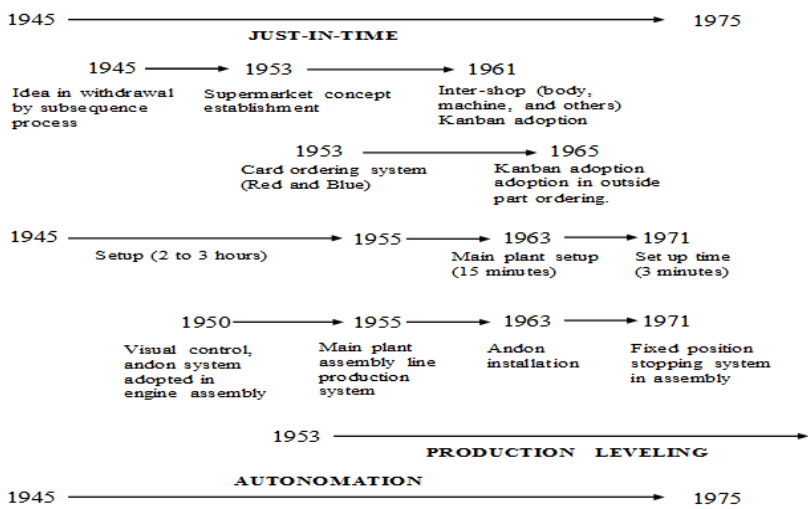

Figure 1: The evolution of TPS: The development of lean tools in TPS Source: Ohno [17]

The contemporary research regarding line WIP inventory control has been demonstrated by researchers such as Oldipupo [3] who researched the Kanban call-in card in fulfilment of uncertain demand whilst keeping a lower WIP inventory level. Savino [14] and Huseyin [16] claim that the design of the WIP line inventory control and materials supply absolutely correlates with the part structure and its sub-parts process parameters, irrespective of whether the control is by Kanban card, supermarket line stocking or just-in-time supplying. Similarly,a case study by Naufal [11] involves creating a pull production system to reduce line WIP inventory. In sum, lean researchers have introduced the pull mechanism for controlling the WIP inventory in a production line. Thus, the processes for keeping the inventory as low as possible involve creating a lean environment for converting raw material to finished product thereby immediately reducing the WIP inventory holding cost.

\subsection{Value Stream Mapping (VSM)}

Value stream mapping (VSM) - another lean technique which involves carrying process information, product (raw material, WIP and finished goods) flow information, customer demand pattern and supplier supplying pattern - had been commonly applied by lean practitioners for the identification of each action performed in an operation and their classification as 'value added' or 'non-value added'. The current holistic view of an operation has been illustrated through VSM, the thinking process involved in the improvement of each operation in terms of material handling, inventory control, process cycle time and other ways of eliminating waste in the entire operation. Labrelato [15] demonstrates the integration of VSM with the thinking process of the Theory of Constraints. The future VSM is predicted by incorporating the diffusion of lean tools into the current VSM during the thinking process. The case study from Lasa [8] on introducing the single minute die exchange concept shows continuous flow eliminating WIP, whereas Harwinder [1] conducted a simulation of 'takt' time for process cycle time improvement and line WIP inventory reduction. From the cost perspective, any improvement will lead to a cost advantage; indeed, Ruiz [13] shows how the establishment of a value stream costing 
framework by determining the actual base cost for each process can be the base for improvement.

by the authors (Cuatrecasas-Arbós [5], Savino [14], Oladipapo [3], Ziengs [19]) in studying inventory from the actual shop floor production parameter perspective, such as process setting time, machine upload efficiency, process cycle time in the overall process and information flow in actual operation. The papers on VSM application by Lasa [8] and Harwinder [1] show that lean tools initially improve the floor activities. In relation to the activity cost base, the case study by Ruiz [13] examined line inventory improvement by embedding lean tools and the initiation of VSM and inventory cost to provide a base reference for reengineering the current operation. Concisely, in this case study, the demonstrating on the floor production parameters in selection of lean tools will be encompassed and the application of VSM in mitigating of the tangible material handling waste and monitoring on the line inventory cost will be considered.

\begin{tabular}{|c|c|c|c|}
\hline $\begin{array}{c}\text { Author } \\
\text { (year) }\end{array}$ & $\begin{array}{l}\text { Research } \\
\text { topic }\end{array}$ & Research scope & $\begin{array}{l}\text { Issues in re- } \\
\text { search }\end{array}$ \\
\hline $\begin{array}{l}\text { Oladipupo } \\
(2013)\end{array}$ & $\begin{array}{l}\text { Evaluation of } \\
\text { production } \\
\text { control strate- } \\
\text { gies for negli- } \\
\text { gible, multi- } \\
\text { product, serial } \\
\text { line with con- } \\
\text { sideration of } \\
\text { robustness. }\end{array}$ & $\begin{array}{l}\text { Conducting a } \\
\text { simulation under } \\
\text { various produc- } \\
\text { tion control } \\
\text { strategy parame- } \\
\text { ters, Kanban } \\
\text { control, CON- } \\
\text { WIP, and base } \\
\text { stock in deter- } \\
\text { mination of op- } \\
\text { timal Kanban } \\
\text { card control al- } \\
\text { location policy } \\
\text { for a multi-prod- } \\
\text { uct system. }\end{array}$ & $\begin{array}{l}\text { The comparison } \\
\text { of three produc- } \\
\text { tion control } \\
\text { strategies from a } \\
\text { robustness per- } \\
\text { spective against } \\
\text { the demand } \\
\text { from the market } \\
\text { under a multi- } \\
\text { product environ- } \\
\text { ment faced vari- } \\
\text { ous process set- } \\
\text { ting times, pro- } \\
\text { cess cycle times } \\
\text { and uncertainty } \\
\text { in the produc- } \\
\text { tion line. }\end{array}$ \\
\hline $\begin{array}{l}\text { Cuatrecasas- } \\
\text { Arbós (2015) }\end{array}$ & $\begin{array}{l}\text { Monitoring } \\
\text { processes } \\
\text { through in- } \\
\text { ventory and } \\
\text { manufactur- } \\
\text { ing lead time. }\end{array}$ & $\begin{array}{l}\text { A study of the } \\
\text { causal relation- } \\
\text { ship within WIP } \\
\text { inventory, man- } \\
\text { ufacturing lead } \\
\text { time and the op- } \\
\text { eration variables } \\
\text { (process cycle } \\
\text { time) to estab- } \\
\text { lish guidelines } \\
\text { and performance } \\
\text { indicators. }\end{array}$ & $\begin{array}{l}\text { Quantitative ap- } \\
\text { proach on the } \\
\text { relationship be- } \\
\text { tween WIP level } \\
\text { against produc- } \\
\text { tion lead time in } \\
\text { making assump- } \\
\text { tions of no } \\
\text { breakdown, no } \\
\underline{\text { delays between }} \\
\text { processes in } \\
\text { WIP movement. }\end{array}$ \\
\hline $\begin{array}{l}\text { Savino } \\
\text { (2015) }\end{array}$ & $\begin{array}{l}\text { A decision } \\
\text { model for se- } \\
\text { lecting part- } \\
\text { feeding poli- } \\
\text { cies in assem- } \\
\text { bly lines. }\end{array}$ & $\begin{array}{l}\text { A research pa- } \\
\text { per focusing on } \\
\text { part-feeding pol- } \\
\text { icies among } \\
\text { just-in-time de- } \\
\text { livery, line stor- } \\
\text { age and kitting } \\
\text { form supply } \\
\text { with the consid- } \\
\text { eration of prod- } \\
\text { uct structure and } \\
\text { inventory hold- } \\
\text { ing cost. }\end{array}$ & $\begin{array}{l}\text { The issue expe- } \\
\text { rienced by the } \\
\text { author was no } \\
\text { inventory cost } \\
\text { drivers in the se- } \\
\text { lection of line } \\
\text { inventory feed- } \\
\text { ing policy and } \\
\text { process cycle } \\
\text { time had been } \\
\text { negligible in the } \\
\text { simulation } \\
\text { model. }\end{array}$ \\
\hline $\begin{array}{l}\text { Zeings } \\
(2012)\end{array}$ & $\begin{array}{l}\text { Placement of } \\
\text { effective } \\
\text { work-in-pro- } \\
\text { gress limits in } \\
\text { a route-spe- } \\
\text { cific unit- } \\
\text { based pull } \\
\text { system. }\end{array}$ & $\begin{array}{l}\text { A research pa- } \\
\text { per on control- } \\
\text { ling a limiting } \\
\text { order (work-in- } \\
\text { progress) pro- } \\
\text { duction floor in } \\
\text { monitoring } \\
\text { throughput time } \\
\text { by developing a }\end{array}$ & $\begin{array}{l}\text { In this study, the } \\
\text { important issue } \\
\text { is no capture of } \\
\text { WIP level in } \\
\text { each stage in a } \\
\text { specified con- } \\
\text { trol-loop (as- } \\
\text { sembly line with }\end{array}$ \\
\hline
\end{tabular}

\subsection{Case Study Gap Analysis}

The literature review for this case study is summarized in Table 1, below.Hereafter, a few issues have been experienced

\begin{tabular}{|c|c|c|c|}
\hline & & $\begin{array}{l}\text { pull system } \\
\text { within a desig- } \\
\text { nated unit-based } \\
\text { system. }\end{array}$ & $\begin{array}{l}\text { in-built sub-as- } \\
\text { sembly). }\end{array}$ \\
\hline $\begin{array}{l}\text { Naufal } \\
(2012)\end{array}$ & $\begin{array}{l}\text { Development } \\
\text { of Kanban } \\
\text { system at a } \\
\text { local manu- } \\
\text { facturing } \\
\text { company in } \\
\text { Malaysia. }\end{array}$ & $\begin{array}{l}\text { The study con- } \\
\text { centrated on the } \\
\text { implementation } \\
\text { of the Kanban } \\
\text { system on the } \\
\text { actual manufac- } \\
\text { turing floor that } \\
\text { is based on the } \\
\text { actual call-in } \\
\text { signal from the } \\
\text { customer. }\end{array}$ & $\begin{array}{l}\text { The issue in the } \\
\text { case study, i.e. } \\
\text { production plan- } \\
\text { ning without } \\
\text { synchronization } \\
\text { of customer de- } \\
\text { mand and } \\
\text { change to a rigid } \\
\text { model, is highly } \\
\text { important. }\end{array}$ \\
\hline
\end{tabular}

\begin{tabular}{|c|c|c|c|}
\hline $\begin{array}{l}\begin{array}{l}\text { Author } \\
\text { (year) }\end{array} \\
\text { year }\end{array}$ & Research topic & Research scope & $\begin{array}{l}\text { Issues in re- } \\
\text { search }\end{array}$ \\
\hline $\begin{array}{c}\text { Librelato } \\
\text { (2014) }\end{array}$ & $\begin{array}{l}\text { A process im- } \\
\text { provement ap- } \\
\text { proach based } \\
\text { on value } \\
\text { stream map- } \\
\text { ping and the } \\
\text { Theory of Con- } \\
\text { straints Think- } \\
\text { ing Process. }\end{array}$ & $\begin{array}{l}\text { The integration } \\
\text { of value stream } \\
\text { mapping and } \\
\text { Theory of Con- } \\
\text { straints Think- } \\
\text { ing Process in } \\
\text { improving } \\
\text { business and } \\
\text { operation pro- } \\
\text { cess modelling } \\
\text { in an organiza- } \\
\text { tion. }\end{array}$ & $\begin{array}{l}\text { Through the } \\
\text { VSM concept, } \\
\text { the inter-related } \\
\text { thinking on the } \\
\text { operational im- } \\
\text { provement had } \\
\text { been established } \\
\text { but lacked an } \\
\text { evaluation of the } \\
\text { actual implemen- } \\
\text { tation. }\end{array}$ \\
\hline $\begin{array}{l}\text { Lasa }(2008) \\
\text { and Har- } \\
\text { winder } \\
(2013)\end{array}$ & $\begin{array}{l}\text { An evaluation } \\
\text { of a value } \\
\text { stream map- } \\
\text { ping tool. Ap- } \\
\text { plication of } \\
\text { lean manufac- } \\
\text { turing using } \\
\text { value stream } \\
\text { mapping in an } \\
\text { auto-parts } \\
\text { manufacturing } \\
\text { unit. }\end{array}$ & $\begin{array}{l}\text { A study on re- } \\
\text { designing the } \\
\text { current produc- } \\
\text { tion system } \\
\text { through value } \\
\text { stream map- } \\
\text { ping and a rec- } \\
\text { ommendation } \\
\text { of lean tools } \\
\text { such as SMDE, } \\
\text { a pull system } \\
\text { and supermar- } \\
\text { ket racking in } \\
\text { reducing pro- } \\
\text { duction param- } \\
\text { eters such as } \\
\text { line inventory, } \\
\text { process cycle } \\
\text { time and setting } \\
\text { time. }\end{array}$ & $\begin{array}{l}\text { The lack of eval- } \\
\text { uation of the ac- } \\
\text { tual environment } \\
\text { on the proposed } \\
\text { lean tools.No } \\
\text { strengths and } \\
\text { weaknesses of } \\
\text { the application } \\
\text { given. }\end{array}$ \\
\hline Ruiz (2013) & $\begin{array}{l}\text { Lean manufac- } \\
\text { turing: costing } \\
\text { the value } \\
\text { stream. }\end{array}$ & $\begin{array}{l}\text { An activity } \\
\text { base cost study } \\
\text { in a lean com- } \\
\text { pany in terms } \\
\text { of WIP cost, di- } \\
\text { rect labour } \\
\text { cost, overhead } \\
\text { cost instead of } \\
\text { the traditional } \\
\text { costing } \\
\text { method. Short- } \\
\text { comings in pre- } \\
\text { senting the ef- } \\
\text { fectiveness of } \\
\text { lean manage- } \\
\text { ment. }\end{array}$ & $\begin{array}{l}\text { The case study } \\
\text { had indicated } \\
\text { cost simulation } \\
\text { in real conditions } \\
\text { but however, } \\
\text { there is no empir- } \\
\text { ical follow } \\
\text { through on value } \\
\text { stream cost. }\end{array}$ \\
\hline
\end{tabular}




\section{Methodology}

The methodology in this case study is divided into three stages. The first stage is based on quantitative data collection to relate the production floor parameters (further described in section 3.1), the second stage is to diagnose the current operation through value stream mapping and the final stage will be the development of lean management tools.

\subsection{Database Establishment}

The selected activity data concerns the line inventory cost level, WIP transportation and production process cycle time. The Methods-Time Measurement (MTM) approach will be introduced in the data collection. In this case study, the primary value chain process indicated in Fig. 2 was drawn for process cycle time measurement. Diaz [2] described cycle time as an essential aspect in determining process efficiency and defined it as the total task from the start until the finish of the process. From Morlock [10], the planning activities required when designing the scope of measurement included each reach, grasp, move, position and release motion. The WIP transportation relates to the straightforward distance travelled and material handled by an operator related to several workplaces illustrated in Fig. 3 for the WIP movement in the plant layout. This is as mentioned by Magu [9] in a study paper involving a path process chart and time and motion study.

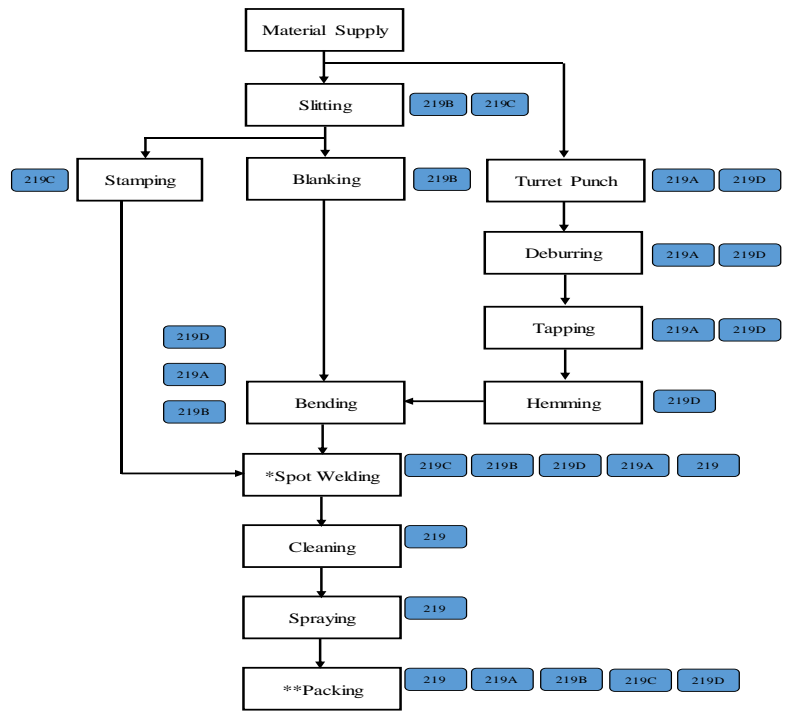

Figure 2: Primary value chain process flow

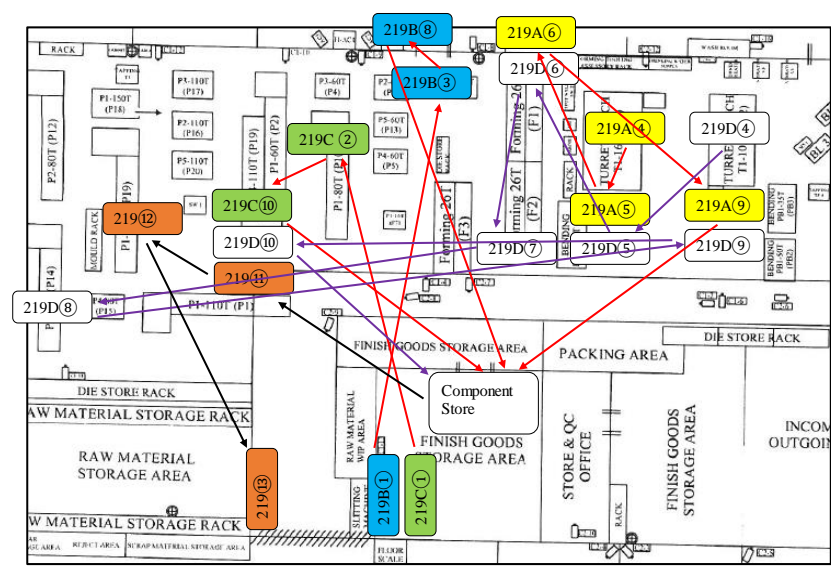

Figure 3: Work-in-progress movement

\subsection{Value Stream Mapping Approach (VSM)}

In the second stage of the research methodology, the application of value stream mapping is the initial implementation of a lean tool in this case study. Lasa [8] and Harwinder [1] successfully integrated lean tools within their current operation by using VSM to reduce cycle time, setting time and line inventory level. However, from the manufacturing costing (overhead cost, inventory cost) perspective, Ruiz [13] presented the simulation of each operation cost through the value stream cost in generating the activity base cost. Therefore, in this case study, the line inventory cost will establish the new current value stream mapping.

\subsection{Lean tools implementation}

The review of the waste in the current value stream mapping had driven the selection of lean tools in mitigating the waste, such as the pull system introduced by Lasa [8] in the future value stream mapping to reduce the line inventory.

In sum, the overall research methodology is illustrated in Fig.4. The current new value stream mapping is constructed by the integration of the lean tools selected to mitigate WIP movement. The result in this case study will describe the trend behavior of the WIP inventory cost.

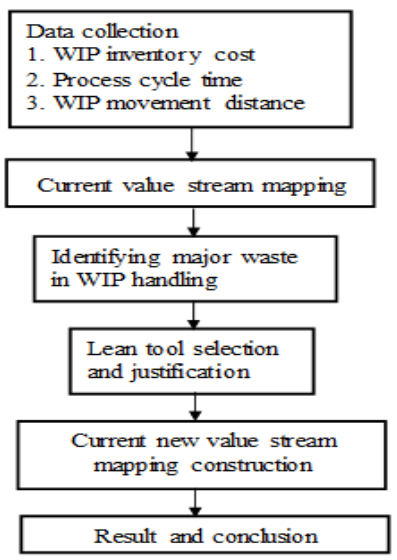

Figure 4: The overall research flow

\section{Result and Discussion}

\subsection{Current Value Stream Mapping}

The data collection on the process cycle time in the primary value process flow incorporating the current business processes such as customer's order, supplier delivery pattern and finished product delivery, had driven the development of the current VSM indicated in Fig.5. The current VSM revealed a majority of 'Muda' waste in transporting material in between the processes. Intuitively and explicitly, the major waste had occurred in transporting the WIP inventory in/out of the component store and the introduction of lean tools had been studied to mitigate the waste at this area. 


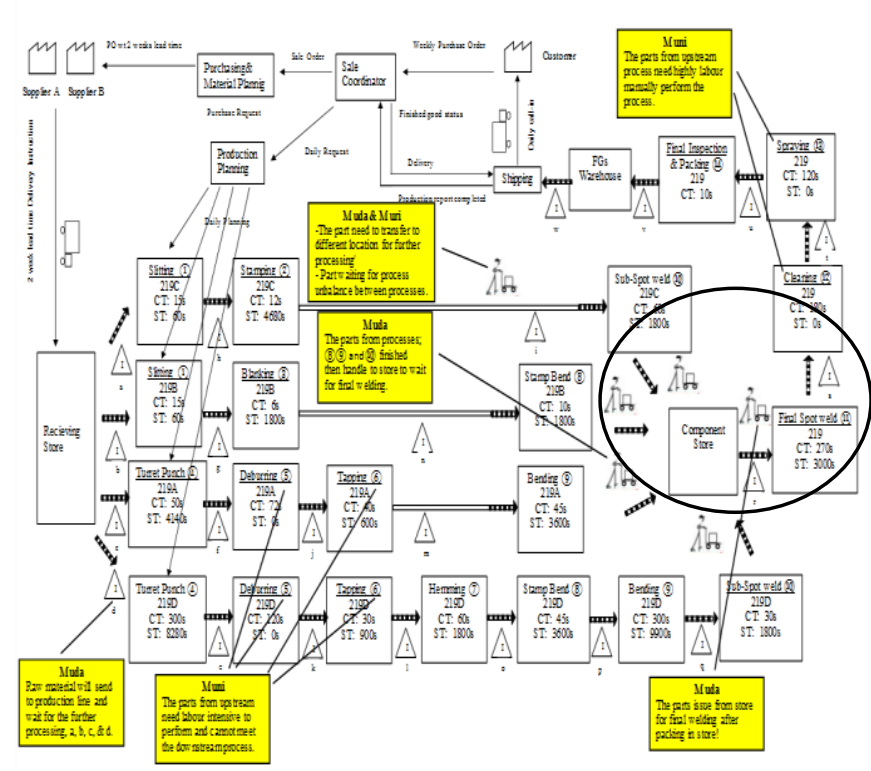

Figure 5: The current value stream mapping

\subsection{Supermarket Racking Concept}

First, a list of lean tools that could eliminate the waste of material in the areas indicated in the above current VSM was rigorously studied. Keeping in view the current plant conditions and the production facilities available given the present shop floor layout, the selection of lean tools was prioritized. It had been decided that the lean tools would be focused on the production control strategy such as those studied by Naufal [11], and Savino [14]. Thus, lean tools like just-in-time continuous supply, Kanban card production instruction and line feeding to the final process along with predefining a WIP inventory level using a specified racking at the line sites (supermarket racking concept) were established. In sum, the three lean tools and their characteristics are presented in Table 2. One piece flow (JIT) aims to achieve continuous flow with a dedicated line for the particular product; supermarket line racking is suitable for the huge differences in location and process cycle times and creates a visual inventory control at the line site; finally, the Kanban instruction card system is good for line inventory control between upstream and downstream processes. As aforementioned regarding the current floor production context, the selection of lean tools had to consider the reluctance to re-allocate the current production facilities due to facilities being shared with other products, thus, either Kanban card instruction or supermarket line inventory racking was introduced. The selected study part (219) consists of four sub-parts (219A, 219B, 219C and 219D) so, inevitably, there are different process cycle times. Hence, the sub-parts process cycle is captured in Table 3 considering the application of the concept used by Morlock [10] in motion time measurement (MTM).

Table 2

\begin{tabular}{|l|l|}
\hline $\begin{array}{l}\text { One piece flow } \\
\text { (Just-in-time) }\end{array}$ & $\begin{array}{l}\text { Reducing the line work-in-progress inventory to the minimum } \\
\text { level by creating the continous processes. }\end{array}$ \\
\hline Supermarket concept & $\begin{array}{l}\text { Reducing the work-in-progress inventory to the require level } \\
\text { after consideration of huge difference of process cycle time } \\
\text { and location of facilities are separate each other. } \\
\text { Visual inventory stock controlling by setting the minimun and } \\
\text { maximum stock level with the consideration of erractic order } \\
\text { from customer. } \\
\text { Base for continous improvement in process, and material } \\
\text { handling. }\end{array}$ \\
\hline $\begin{array}{l}\text { Instruction Card } \\
\text { Kanban) }\end{array}$ & $\begin{array}{l}\text { Production start by following the instruction card from the } \\
\text { down stream process. Improving the access inventory in line. }\end{array}$ \\
\hline
\end{tabular}

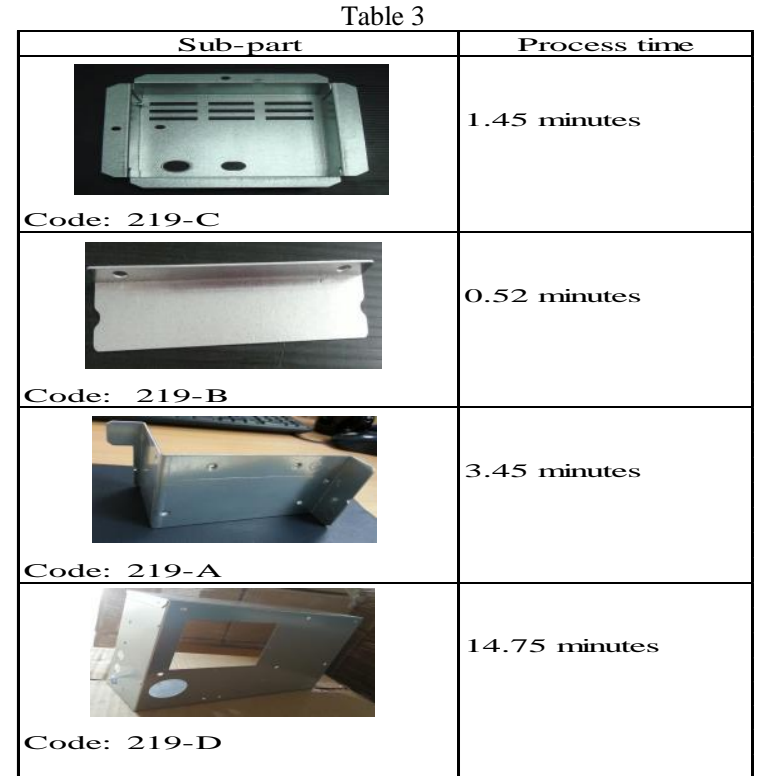

Referring to Table 3, there is huge cycle time variation among the sub-parts, from 0.52 minutes to 14.75 minutes; thus either applying Kanban card or supermarket racking in the current production line for 219 was considered. In the case of implementing the Kanban card system, a drastic line balancing between the processes would be required. Line supermarket racking would enable WIP storage with a defined inventory level. Therefore, implementing supermarket racking was more appropriate and brought an immediate effect without major changes in the current production line layout.

The study considers the 219A, 219B and 219C inventory levels that give the least processing and that most processes involve 219D, as illustrated in the current VSM. The feeding policy applying in this case is establishing maximum (upper) and minimum (lower) inventory levels for 219A, 219B and 219C. The readiness for these to support the final spot welding with 219D is high. Thus, 219D is planned according to the actual customer orders.

The benchmarks and base line for establishing the upper and lower inventory levels for 219A, 219B and 219C were established by reviewing the actual demand pattern from customers within the period from April to October 2017. An empirical study to determine the upper and lower stock levels for the sub-parts was conducted based on the data illustrated in Appendix 1 by applying normal distribution with the central limit theorem and with a confidence level of $95 \%$. The calculation shows that the average demand from 32 part deliveries is 169 sets, however, there are $11(34 \%)$ part deliveries above the average demand, therefore, to handle the abnormal demand, the size of the safety factor in the initial forecast was discussed with the management and marketing members (refer to the meeting on $30^{\text {th }}$ June 2017). The safety factor multiple on the upper stock limit after the discussion was obtained by a consensus agreement of the members based on their intuitive experience in handling this product. Keeping the highest customer demand in view, although in normal demand circumstances the demand is lower than the upper stock limit, the production plan considers that there will be sufficient sub-parts (i.e. 219A, 219B and 219C) to support 219D and to mitigate the build-up of high inventory level costs for finished goods (219).

From 32 deliveries within a period of six months and the maximum demand quantity of 640 sets in a delivery; the proportion compared to the upper stock limit is a ratio of about 1:4. The upper stock limits for 219A, 219B and 219C will be a multiple of 4, whilst the lower stock limit will be a factor of 2 of the upper stock limit. However, as the main sub-part to pull the other three sub-parts, 219D had been constrained at 102 units per production planning lot based on the design bin packing style, explicitly, the stock quantities for sub-parts 219A, 219B and 219C had been designed based on 102 units per lot which depends on the part usage in 219. Table 4 illus- 
trates the summary of the WIP stock level; the information was included in the production planner and given to the production staff for stock level monitoring and control. Nevertheless, 219D was planned at 204 units in each production lot plan, inevitably, at any time junction, there is a lot of 219D WIP in the production line transferring between its processes, and the inventory levels for 219A, 219B and 219C remain within the upper limit. As the inventory levels for 219A, 219B and 219C are visible, the production plan will initiate for 219A and $219 \mathrm{C}$ once the inventory drops below 357 units and 714 units respectively, whilst the balance quantity plan is based on the upper inventory limit: 714 each for 219A and $219 \mathrm{C}$ and 1428 for $219 \mathrm{~B}$.

\begin{tabular}{|c|c|c|c|c|c|c|c|c|}
\hline No & Sub-part & $\begin{array}{c}\text { Usage } \\
\text { per set }\end{array}$ & $\begin{array}{c}\text { UCL } \\
\text { Demand }\end{array}$ & $\begin{array}{c}\text { Table } \\
\text { Required } \\
\text { Quantity }\end{array}$ & $\begin{array}{l}4 \\
\text { Safety St } \\
\text { Upper }\end{array}$ & $\begin{array}{l}\text {-k factor" } \\
\text { Lower }\end{array}$ & $\begin{array}{c}\text { Proposed } \\
\text { Upper }\end{array}$ & $\begin{array}{l}\text { 1 Level } \\
\text { Lower } \\
\text { Lower }\end{array}$ \\
\hline 1 & $219 \mathrm{~A}$ & 1 & 175 & 175 & $\begin{array}{l}\text { Cpper } \\
700\end{array}$ & $\begin{array}{c}\text { Lower } \\
350\end{array}$ & $\begin{array}{l}\text { Cpper } \\
714\end{array}$ & $\begin{array}{c}\text { Lower } \\
357\end{array}$ \\
\hline 2 & $219 \mathrm{~B}$ & 2 & 175 & 350 & 1,400 & 700 & 1,428 & 714 \\
\hline 3 & $219 \mathrm{C}$ & 1 & 175 & 175 & 700 & 350 & 714 & 357 \\
\hline 4 & $219 \mathrm{D}$ & 1 & 175 & 175 & & ton cust & omer demar & \\
\hline
\end{tabular}

1. Safety Stock
Inventory cost

2. Proposed level"* defined as rounding up the stock quantity in multiples of 102 units as the standard
packing quantity

\subsection{WIP Handling and Inventory Improvement}

The WIP sub-parts had been transported from each end process to the component store as previously, refer to Fig.6, and illustrated in the current VSM. The sub-part racking with the bin storage style has been fabricated. The racking had been placed at the final spot welding for CBA219 after consideration of the movement of 219D WIP to minimize the material handling. Fig.7 illustrates the location of the racking in the actual plant layout; however, the material handling for 219A, 219B and 219C had been reduced compared to the sub-part moving to the component store and being issued-out for final spot welding to eliminate the waste involved in double handling.

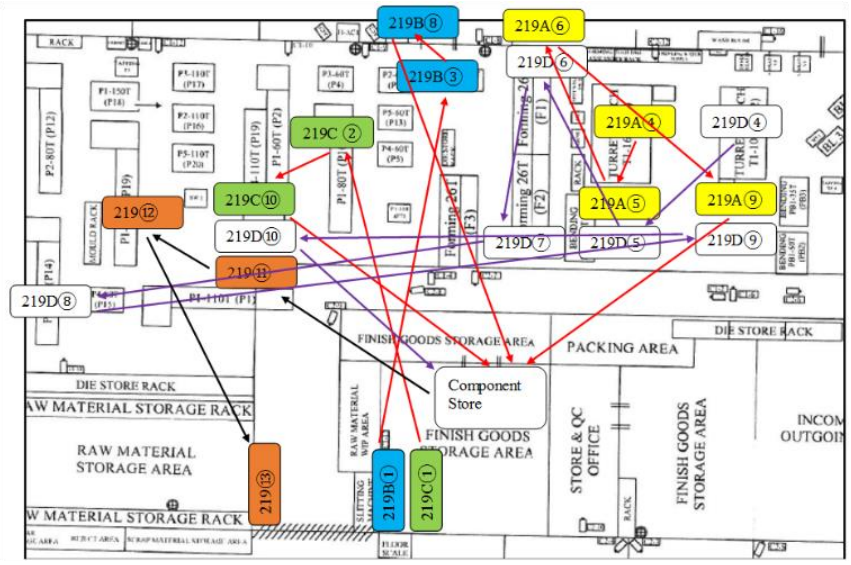

Figure 6: WIP movement before introducing supermarket racking.

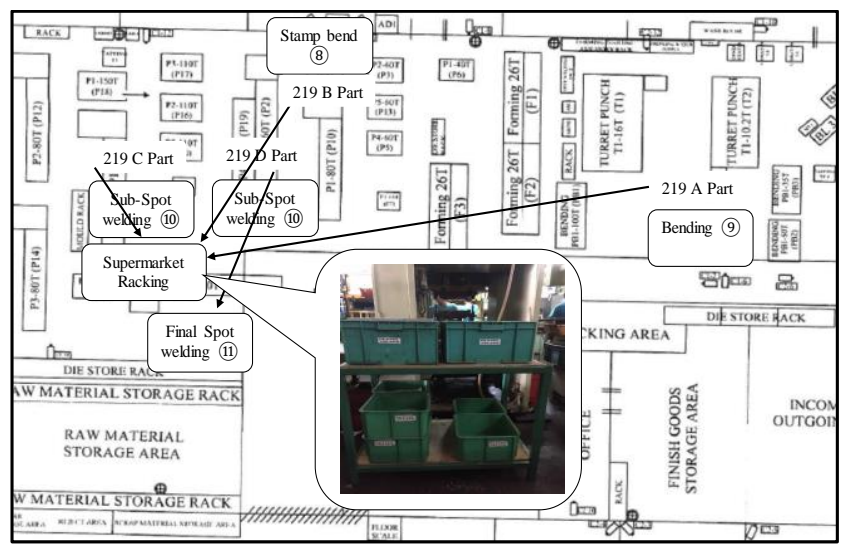

Figure 7: WIP movement after introducing supermarket racking

As mentioned in problem No.3, inconsistency of the production WIP inventory level for the sub-parts in each production plan on the shopfloor resulted from large variances in the production process. The WIP cost trend was plotted based on the unit cost for 219A at RM2.16/pc, 219B at RM1.04/pc, 219C at RM0.78/pc and 219D at RM18.18/pc, from March 2017 to July 2017 and indicated that the WIP inventory cost fluctuated between RM10,642 and RM3,593, thus, indicating that retaining the WIP inventory is unpredictable and the lead time for each production planning period is unstable. Upon implementing the supermarket racking (from August 2017), the WIP inventory cost had been held at the maximum level with a cost of RM5,438 with the sums of RM1,542 for 219A, RM1,485 for 219B, RM556 for 219C and RM1,854 for the WIP cost of 219D each time a lot of 102 units was processed. Fig. 8 presents the trend of the WIP inventory movement. The trend illustrated before implementing line supermarket racking showed a fluctuating WIP inventory thus making it difficult for any improvement on the production process for each sub-part if treating the WIP level as the key performance improvement action as stated by Cuatrecasas-Arbós [5]. The implementation of supermarket racking at the line site effectively stabilized the WIP inventory cost at the specified level and established a base for further improvement. Nevertheless, the production lot and the inventory limits will be revised from each review of the warehouse (customer) demand.

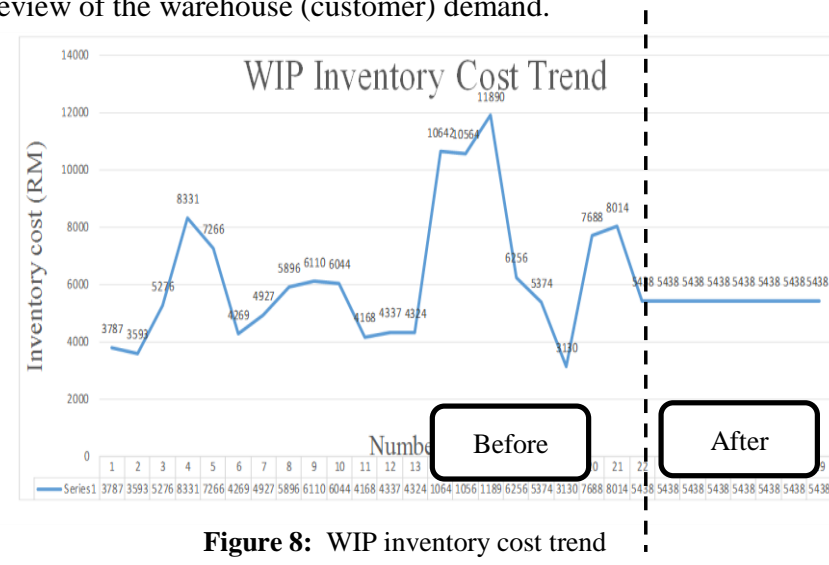

Simultaneously, the developing of the new current VSM is demonstrated in Fig. 9 after the implementation of the supermarket racking concept as an initial improvement for the product (part 219).

\section{Implications and Conclusion}

In the manufacturing context, the daily operation on the shop floor is bound to produce waste, and frequently this waste is hidden from the shop floor management team. Indeed, the result from this case study revealed the strength of VSM in demonstrated the holistic operation and waste identification as with other VSM case study researchers. Hence the implementation of a supermarket racking production strategy in creating line storage in resolving problems Nos. 2 and 3. It is noteworthy, in this case study, that the WIP inventory cost level had been defined as the key measurement for process improvement towards continuous flow and congruence with Cuatrecasas-Arbós [5] in evaluating production lead time from the WIP level. Although this case study is limited to a particular product, it has sown the seeds of lean concept thinking within the organization and the evolution of lean management will continue with the aim of achieving a lean organization. 


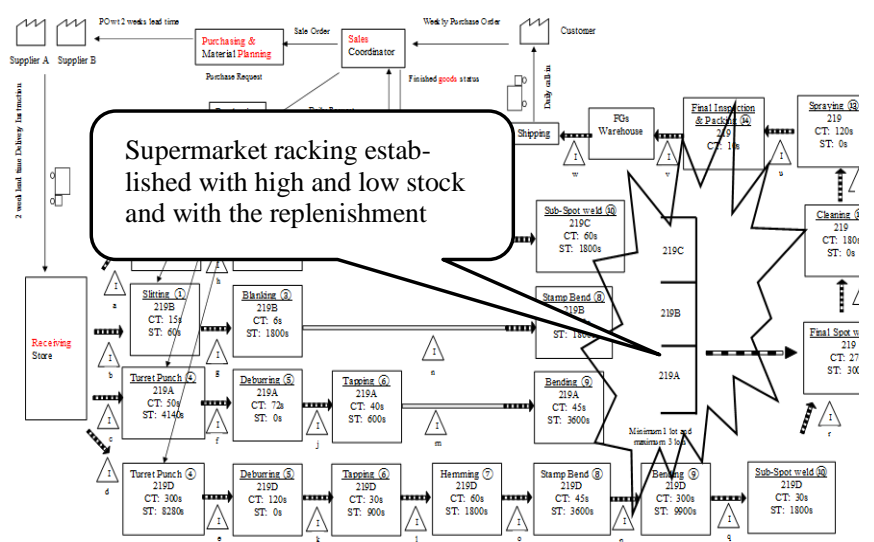

Figure 9: The establishing of the new current VSM

\section{Acknowledgement}

The completion of this study, I would like to express my thankfulness to my academic supervisor and the management team from the company. Along the case study, they had shared their valuable knowledge and experiences with me, encouragement from them to me and enable me to overcome the barriers in implementing new improvement. Hereby, I wish a special gratefulness to the quality departmental manager that always giving me a helping whatever I requisition in some difficult matter.

\section{Appendix}

\section{Actual Delivery Data}

\begin{tabular}{|c|c|c|c|c|c|}
\hline No & Delivery Date & Quantity & $\mathbf{X}_{\mathbf{i}}$ & $\mathbf{X}_{\text {ave }}$ & $\mathbf{X}_{\mathbf{i}}-\mathbf{X}_{\text {ave }}$ \\
\hline 1 & $10 / 04$ & 10 & 10 & 169 & -159 \\
\hline 2 & $12 / 04$ & 115 & 115 & 169 & -54 \\
\hline 3 & $08 / 05$ & 69 & 69 & 169 & -100 \\
\hline 4 & $11 / 05$ & 204 & 204 & 169 & 35 \\
\hline 5 & $17 / 05$ & 10 & 10 & 169 & -159 \\
\hline 6 & $24 / 05$ & 49 & 49 & 169 & -120 \\
\hline 7 & $26 / 05$ & 681 & 681 & 169 & 512 \\
\hline 8 & $29 / 05$ & 53 & 53 & 169 & -116 \\
\hline 9 & 05/06 & 2 & 2 & 169 & -167 \\
\hline 10 & $14 / 06$ & 5 & 5 & 169 & -164 \\
\hline 11 & $21 / 06$ & 12 & 12 & 169 & -157 \\
\hline 12 & $19 / 07$ & 173 & 173 & 169 & 4 \\
\hline 13 & $07 / 08$ & 96 & 96 & 169 & -73 \\
\hline 14 & $10 / 08$ & 640 & 640 & 169 & 471 \\
\hline 15 & $21 / 08$ & 409 & 409 & 169 & 240 \\
\hline 16 & $23 / 08$ & 240 & 240 & 169 & 71 \\
\hline 17 & $28 / 08$ & 20 & 20 & 169 & -149 \\
\hline 18 & 04/09 & 22 & 22 & 169 & -147 \\
\hline 19 & 06/09 & 376 & 376 & 169 & 207 \\
\hline 20 & $07 / 09$ & 300 & 300 & 169 & 131 \\
\hline 21 & $07 / 09$ & 14 & 14 & 169 & -155 \\
\hline 22 & $13 / 09$ & 107 & 107 & 169 & -62 \\
\hline 23 & $27 / 09$ & 308 & 308 & 169 & 139 \\
\hline 24 & $28 / 09$ & 244 & 244 & 169 & 75 \\
\hline 25 & $28 / 09$ & 158 & 158 & 169 & -11 \\
\hline 26 & $04 / 10$ & 20 & 20 & 169 & -149 \\
\hline 27 & $06 / 10$ & 328 & 328 & 169 & 159 \\
\hline 28 & $11 / 10$ & 144 & 144 & 169 & -25 \\
\hline 29 & $13 / 10$ & 2 & 2 & 169 & -167 \\
\hline 30 & $24 / 10$ & 2 & 2 & 169 & -167 \\
\hline 31 & $25 / 10$ & 455 & 455 & 169 & 286 \\
\hline 32 & $26 / 10$ & 151 & 151 & 169 & -18 \\
\hline
\end{tabular}

$\mathrm{X}_{\mathrm{ave}}=5419 / 32=169.3 \approx 169$

$\delta=\sqrt{ } 11^{2} / 31=1.97$

\section{References}

[1]. Singh Harwinder, Singh Amandeep, Application of lean manufacturing using value stream mapping in an auto-parts manufacturing unit, Journal of Advances in Management Research 10(1)(2013) 72-84.

[2]. I. C. Diaz, et al.,Cycle time study of wing spar assembly on aircraft factory, Procedia Manufacturing 13(2017) 1019-1025.

[3]. Oladipupo A. Olaitan, John Geraghty, Evaluation of production control strategies for negligible-setup, multi-product, serial lines with consideration for robustness, Journal of Manufacturing Technology Management 24(3) (2013) 331-357.

[4]. C. Madhusudhana Rao, K. Prahlada Rao, Inventory turnover ratio as a supply chain performance measure, Serbian Journal of Management 4(I) (2009) 41-50.

[5]. L. Cuatrecasas-Arbós, et al., Monitoring processes through inventory and manufacturing lead time, Industrial Management \& Data Systems 115(5) (2015) 951-970.

[6]. A. M. Deif, H. ElMaraghy, Impact of Dynamic Capacity Policies on WIP Level in Mix Leveling Lean Environment, Procedia CIRP 17 (2014) 404-409.

[7]. J. Fang, et al., Event-driven multi-agent ubiquitous manufacturing execution platform for shop floor work-in-progress management, International Journal of Production Research 51(4) (2013) 1168-1185.

[8]. I. S. Lasa, et al.,An evaluation of the value stream mapping tool, Business Process Management Journal 14(1) (2008) 39-52.

[9]. P. Magu, et al., Path Process Chart - A Technique for Conducting Time and Motion Study, Procedia Manufacturing 3 (2015) 64756482.

[10]. F. Morlock, et al., Teaching Methods-Time Measurement (MTM) for Workplace Design in Learning Factories, Procedia Manufacturing 9 (2017) 369-375.

[11]. A. Naufal, et al., Development of the Kanban System at a Local Manufacturing Company in Malaysia-Case Study, Procedia Engineering 41 (2012) 1721-1726.

[12]. H. T. Papadopoulos, M. I. Vidalis, Minimizing WIP inventory in reliable production lines, International Journal of Production Economics 70(2) (2001) 185-197.

[13]. P. Ruiz-de-Arbulo-Lopez, et al., Lean manufacturing: costing the value stream, Industrial Management \& Data Systems 113(5) (2013) 647-668.

[14]. M.M. Savino, A. Mazza, Kanban-driven parts feeding within a semiautomated O-shaped assembly line: a case study in the automotive industry, Assembly Automation 35(1) (2015) 3-15.

[15]. T. P. Librelato, et al., A process improvement approach based on the Value Stream Mapping and the Theory of Constraints Thinking Process, Business Process Management Journal 20(6) (2014) 922 949.

[16]. Huseyin Selcuk, Menmet Bulet Durmusoglu, Advances in assembly line parts feeding policies: a literature review, Assembly Automation 35 (1) (2015) 57-68.

[17]. Taiichi Ohno, Beyond Large-Scale Production, CRC Press, New York, 1990.

[18]. Zhang, Y. et al., Real-time work-in-progress management for smart object-enabled ubiquitous shop-floor environment, International Journal of Computer Integrated Manufacturing 24(5) (2011) 431-445.

[19]. Ziengs, N., et al., Placement of effective work-in-progress limits in route-specific unit-based pull systems, International Journal of Production Research 50(16) (2012) 4358-4371. 